IRSTI 03.20 .00

\author{
Abdildabekova A.M. \\ Candidate of historical sciences, Associate Professor, \\ al-Farabi Kazakh National University, \\ Kazakhstan, Almaty, e-mail: abdiaigul@mail.ru
}

\title{
JOINING OF THE KAZAKH LANDS TO THE RUSSIAN EMPIRE: HISTORIOGRAPHICAL REVIEW XIX - EARLY XX CENTURY
}

At present, new facets are being discovered in covering and identifying important issues in the relations between Kazakhstan and Russia in the 18th and early 20th centuries. Appeal to historical research on this issue from the standpoint of rethinking the views of the authors is necessary and timely. In this context, the work of Russian researchers who were in Kazakhstan in the service is of great interest. The authors wrote about contemporary events for them, and in their views were dependent on the influence inherent in imperial ideology. The works are characterized by descriptiveness, a weak source base, the absence in some cases of historical interpretation of factual data, and groundless conclusions and generalizations. The works of Russian authors can be classified according to directions and theories: the theory of «natural borders», the theory of ethnographic and geographical factors, chauvinistic direction, the direction of "civilizing mission.»

A large number of materials in Russian historiography devoted to the acceptance of Russian citizenship by the Kazakh zhuzes testifies to the interest in this problem. But this interest is due to the desire to learn the history of the indigenous people for the successful implementation of the colonial policy of tsarism.

Key words: kazakh zhuzes, Kazakh-Russian relations, colonization, citizenship, accession.

\author{
Аблилдабекова А.М. \\ тарих ғылымдарының кандидаты, доцент, \\ әл-Фараби атындағы Қазақ ұлттық университеті, \\ Қазақстан, Алматы қ., e-mail: e-mail:abdiaigul@mail.ru

\section{Қазақ жерінің Ресей империясының құрамына енуі: XIX ғ. - XX ғасырдың басындағы тарихнамаға талдау}

\footnotetext{
Қазіргі уақытта тарих ғылымында жаңа теориялық-концептуалдық әдістердің қалыптасуы мен оның Қазақстанның жаңа тарихына қолданыла бастауы XVIII ғасыр мен XIX ғасырдың бас кезіндегі Қазақстан мен Ресей қатынастарындағы маңызды мәселелерді жаңа қырынан көрсетуге мүмкіндік туғызып отыр. Авторлардың ғылыми көзқарастарын қайта пайымдау тұрғысынан қарағанда бүгінгі уақытта аталған проблема бойынша ғылыми тарихи зерттеулерге жүгіну аса қажетті мәселелердің бірі.

Осы мәселеде Қазақстанда қызмет бабымен болған орыс зерттеушілерінің еңбектеріне ерекше назар аударылған. Олардың сол кезеңдегі оқиғаларды баяндауда империялық саясатқа тәуелді болуын назарға алған. Еңбектердің басым бөлігінде сипаттау тән, деректік қоры төмен. Сонымен қатар жалпылау, фактілерді негіздеу, анықтама берудің кездеспейтіндігін атап өтеді. Авторлардың еңбектерін тұжырымдық жағынан төмендегідей бөліп қарастырған: «табиғи шекаралар», этнографиялық және географиялық, шовинистік және «өркениеттік миссия» факторларына біріктіреді. Орыс тарихнамасындағы еңбектердің ауқымдылығы бұл мәселенің өзектілігін көрсетеді. Бірақ, оның астарында империялық отарлау саясатының жатқандығын анық, көруге болады.
}

Түйін сөздер: қазақ жүздері, қазақ-орыс қатынастары, отарлау, қол астына қабылдау, қосылу. 


\title{
Абдилдабекова А.М. \\ кандидат исторических наук, Аоцент, Казахский национальный университет имени аль-Фараби, Казахстан, г. Алматы, e-mail: abdiaigul@mail.ru \\ Вхождение казахских земель в состав Российской империи: историографический обзор XIX - начала XX века
}

\begin{abstract}
В настоящее время открываются новые грани в освещении и определении важных вопросов взаимоотношений Казахстана и России в XVIII - начале XX веков. Обращение к историческим исследованиям по Аанной проблеме с позиции переосмысления взглядов авторов является необходимым и своевременным. В Аанном контексте вызывают большой интерес работы русских исследователей, находившихся в Казахстане по службе. Авторы писали о современных для них событиях и в своих взглядах были зависимы от влияния присущей им имперской идеологии. Аля работ характерны описательность, слабая источниковая база, отсутствие в ряле случаев исторического осмысления фактических Аанных, необоснованность выводов и обобщений. Работы русских авторов можно классифицировать по направлениям и теориям: теория «естественных границ», теория этнографических и географических факторов, шовинистическое направление, направление «цивилизаторской миссии».

Большое количество материалов в русской историографии, посвященных принятию подАанства России казахскими жузами, свидетельствует об интересе к данной проблеме. Но интерес этот вызван желанием узнать историю коренного народа для успешной реализации колониальной политики царизма.
\end{abstract}

КАючевые слова: казахские жузы, казахско-русские отношения, колонизация, подАанство, присоединение.

\section{Introduction}

Nowadays formation of new theoretical-methodological approaches applied to understand new history of Kazakhstan opens new facets in shedding light and defining important issues in relations between Kazakhstan and Russia in XVIIIearly XX centuries. Appeal to scholarly historical researches on that problem from the position of reconsidering scientific views of authors is necessary and timely.

Reconstruction of true picture of the past with the employment and analysis of all scope of sources is one of the indispensable conditions of historical sciences development. Understanding of the past, drawing a historical experience from it that can help in solution of modern day problems is the mission of history as the science, but the history of historical science. Geopolitical location of Kazakhstan, its multiethnic population, development of the national idea necessitate indepth, devoid of abstract and simplified approaches study of history of the Kazakh statehood. The relations between the states are based on centuries long historical links between the peoples of Russia and Kazakhstan, full of dramatic collisions, sharp contradictory stratagems, grave social and national conflicts and light and smooth friendly contacts between two peoples.

\section{Methodology and sources}

Historiographic frameworks of the research embrace the period from accumulation of materials, special works on history of Kazakhstan's joining, Russia (XIX century) till the historical concepts formulation (XX century). Great emphasis was paid to the conceptual approaches developed in the soviet times that significantly transformed over time. The need of complex analysis of that problem is stipulated by the desire to consider dominating idea, views, discriminate between them and find the issues under discussion.

In 1730s the Kazakh community started directly contacting with Russia. The Russian historiography of XIX-early XX century emphasizes that emergence and development of relations between Russia and Kazakh community was inevitable natural historical process, due to geographical location of territories under Kazakhs in the bordering areas with the Russian state. Russian researchers explain further advance of tsarism in-depth of the Kazakh steppe by the necessity to defend the borders from the nomadic raids, patronage provision to Kazakh tribes that became Russian subjects. Later on the authors (participants of the events) reveal the predatory politics of tsarism, and put forward the military aspects in conquering the Central Asian khanates. Main attention is dwelt upon military actions, op- 
erations' tactics. That approach we found in the research of N. Belyavsky «Materials on Turkestan». The authors writes: «Gradually step by step, without resistance and even being sympathized by majority of Kygryzes, within 16 years, from 1824 to 1838 , the forward military posts reached...» (Belyavsky, 1885: 3), further defining the Russian influence borders. But in 1845 the patronage was adopted in «the Great Horde as well as in the Middle Horde, were built Qazak settlements, that reinforced the Russian power and provided the troops with the bread $»(\mathrm{Be}-$ lyavsky,1885: 3). Further movement was explained by «the moral need to defend its subjects». The author highly estimates the measures on Turkestan kray arrangements, aimed to strengthen the Russian power that is not surprising for the official of the tsarist administration. In the similar context were written the works of M.A. Terentiev, F. Tsherbina, M. Yudin, M.V. Lavrov, P.P. Rumyantsev, their material layout scheme is quite simple: Asia;

- grounding of the Russian expansion to Central

- a short excursion into history;

- a concise factological presentation of the material;

- description of the measures to strengthen the power of Russia.

Thus, the authors hold one opinion line in proving the interest of Kazakhs in joining Russia and its further advance in-depth the Central Asia to provide security to its borders that was within the dominant conceptual approach. In the works of the Russian researchers we found some criticism of the tsarist administration, the fact of the punitive actions are omitted and even if they are given are interpreted as forced measures. It should be noted that we observe wrong layout of the historical events to please the interests of Russia in order to justify tsarist policy, and such an approach is characteristic for the works to come.

For instance, the work of K.K. Abaza is rather interesting - 'Conquest of Turkestan», where the author employs the works of the above-mentioned authors, that he mentioned in the introduction and came to the following conclusions: the first military activities on the territory of Central Asia demonstrated weak points of the Asians (lack of courage and firmness) and the victory "over them is achieved quite easily, although the price is cheap: being broken apart, the Asians with the same speed easily gather. In order to secure the victory, we must seize their cities and fortresses, and subjugate to the population to our power» (Abaza, 1902: 64). The work proves the superiority of the tsarist army and martial art. "That way of the war conduct drew the Russian troops against their will into the new lands conquest. Despite the desire of our military commanders to avoids direct conflicts, and settle all things peacefully, they against their will had to go forward and forward until they reached the mountains» (Abaza, 1902: 65). Further military activities, in opinion of K.K. Abaza, were to settle three centuries long dispute inherited form the Peter the Great times: whether the Central Asia will stay in semi-slavish position and ignorance or would enjoy the benefits brought by the Russian power.

Presentation and characteristics of the measures taken by the tsarism to strengthen its power (or colonial politics, in other words), is given in the works of V.V. Grigoriev, G. Potanin, M.I. Venukov, Y.V. Kologrivov, N.A. Dingelshtadt and others. For example, G.Potanin in «Notes on the Siberian Qazak troops» pointed that the Kazakh steppes do not posit great threat and therefore there is no need to employ military colonization: «Sure, it is impossible to realize free colonization: it must be limited by familiar areas, so that the Russian colonization would not constrain the migrating Kyrgyzes» (Potanin,1861: 31). M.I. Venukov in the research «Gradual expansion Russia to Middle Asia», when giving analysis of some activities of the tsarism, stressed that Qazak and peasants' villages - as types of the Russian sedentarism - are useful to strengthen the Russia's grandeur and to accustom the indigenous population to peaceful, civilized life. The author disagreed with the statement that the Turkestan kray is under the military administration, as is it was military encampment and that affects the reforms' realization, but at the same time he stressed: «As for the arrangements and administration of the Turkestan kray all the criticism, naturally, must be condescending because the joining of that country happened quite recently and still goes on ...» (Venukov, 1878: 165).

It should be noted that when considering the colonial policy realization, the researchers did not take into account specifics of the agrarian relations among the nomads. The authors mistakenly represented the kray as poorly populated, uncontrollable, and the conclusions made by G.Potanin were rare exception.

What reasons for the expansion of the tsarist troops in-depth the Kazakh steppe are given in the works of the Russian researchers? They are as follows:

- protection from the nomads' raids;

- further erection of the military fortifications is justified by the subjects' protection; 
- Power strengthening and life quality improvement leads to the interest of the Great Horde to adopt the Russian patronage;

- penetration into the Kazakh steppes facilitated access to the central Asian markets;

- absence of the strong resistance from the local population.

Thus, in the article of I. Lvov «Conquest of Turkestan» the Russian expansion to Central Asia is explained by the following reasons: «riots produced by the nomads, constraints to the Russian merchants at the local markets, and especially raids on our territories from the Kokand could not be left unattended» (Lvov, 1868: 153). The opinion that conquest of new territories as a forced, defensive measure got wide theoretical circulation. It should be noted that in the works of pre-revolutionary authors (L.F. Kostenko, M.I. Venukov, S.V. Zhukovlsy) we find the first attempts to connect the policy in the Central Asia with the successes in other directions of the tsarist foreign policy, disclose the competition between Russian and England.

Further on we will classify the works by directions and theories that were developed in the Russian historiography of XX century. In the works of M.I. Venukov is proved the theory of «natural borders», consisting of the elements - defensive policy of Russia, protection from the nomads' raids, joining to the European culture, etc. The author paid much importance to the consecutive advance of Russia into the Central Asia and noted: «From the point of view of the natural history of a man, that movement must be called re-establishment or proliferation of the Arian race in the countries that for a long time were under the dominance of the Turkic or Mongol root's peoples» ...» (Venukov, 1878: 1) looks at the movement form various view points: in economic sense - gradual establishment of universal (European) daily needs; in moral sense - expansion of the Christianity; in educational and scientific terms - development of humanitarian knowledge and the exploration of the kray; in civic sense - rapprochement with the developed nations. "Finally in the political sense our successes in the Middle Asia have become important too: for Russia itself - gradual closing with its natural border limits, most beneficial for it, for Asia - as completion of subjugation of almost half of the population to one power and for humankind in general - as movement of one powerful European people to meet the other, that has already seized the riches countries of the East and scaring that it could lose them and power over them» ...» (Venukov, 1878: $4)$, the other country is England. The author proves inevitability of the Central Asia' conquest by Russia: «no other outcome could happen. To occupy gradually, strips by strips all Central Asian steppes not taken by the Chinese - is a miserable fate of Russia, that it could have avoided it if the steppes had been occupied by another civilized people from the south or east. But there are no such people, and we have alone to pull that historical burden » ...» (Venukov, 1880: 135).

Very close to the theory of «natural borders» a direction that proves the Russian conquests by ethnographic and geographic factors. That theory was developed in the works of A.I. Maksheev, who outlined it in the following: Russian movement southwards, through the Kazakh steppes directly proceeds from the geographic and ethnographic conditions the Russian state was framed in. Each people depends first of all on the territory he populates: so people inhabiting the mountains due to complicated communication form small states, and population living in the valleys strives to form vast states with more or less definite borders. «Russian having started their historical life on the vast East European plain, that via Aral-Caspian lowlands joins much more spacious North-Asian (Siberian) plain, naturally were doomed to spread along that greatest plain in the world, and in their movement eastward ... reached the Great Ocean. From the south they aspired to protect their advance by natural borders, but in some places they crossed them, and in some other places did not even reach» (Maksheev, 1890: 43). That strive of the Russians, in the author's opinion, was contributed by the ethnographic conditions. Proving the fact, the historical role of the people in the east of Europe was given to Russians, A.I. Maksheev points that once it was disputed by the Tartars, and that was the struggle of two civilizations: Christian and Muslim, but from the XVI century, having won in that struggle, the Russians continued the way forward. Gradually, «among the inorodtsys, they established form control due mainly to national character, distinguished by softness and tolerance. The history of the Russians colonial expansion is not free from commonplace facts of injustice and violence, but nowhere it presents contempt and hatred to the aliens («inorodtsy») (Maksheev, 1890: 44). The author emphasized friendliness of Russians, and stated that not due to the arms but by moral qualities of its people Russia could strengthen its dominance in Europe and Asia. So, in opinion of A.I. Makshev, main reasons of the Russian conquests were geographic and ethnographic factors, but he in the wrong way interpreted the importance of economic and political considerations - that fact 
that was of paramount significance in the conquests of the European states.

In the article «Establishment of the Russian power in Central Asia », published in «Military collection» - magazine issued since 1858 that reflected the official position of the government and military administration was a notion: «It should be said without exaggeration that that expansion was made on the initiative of the people themselves: the government had nothing to do but to follow it and through its power to strengthen for Russia what was occupied by chance, without any efforts and expenditures from its side» (Voyennyy sbornik, 1898: 248). We consider that such statement causes strong criticism as it dose not correspond to historical truth, and not only from the present days position. The authors pointed that the expansion conditioned by geographic and ethnographic factors, led to purely political and economic results, in general the article reflected ethnogeorgraphic direction and «natural borders» theory.

Another direction in the Russian historiography that propagated chauvinistic views, although elements of chauvinism are met in all the above-mentioned directions, but representatives of that one proliferated ideas of the Russian nation exclusiveness in its expansion eastward using military force and aggression. In the work of Terentiev M.A. is given the following proof for the conquest of Central Asia: «History of our further expansion to the East is in general characterized by the following: neighborhood with savage, that did not recognize any international or other rights, expect for the right of force, compelled us to fortify the frontiers with the line of fortresses ...» (Terentiev, 1906: 6). The author connects Russia's successes only with the use of armed forces in Asia. Employment of the words «savage», «small peoples», «steppe» to designate the peoples of Kazakhstan and Central Asia was abusive. Such approach is typical for A. Shemonsky too, who wrote that «for a long time of the Russians fuss with the steppe ... was defined the very character, manner - purely Russian - of politics and war conduct against the steppe inhabitants» (Shemonsky, 1910: 122). The author stressed that good neighborhood relations with the steppe settlers could be achieved only with the use of arms and military activities for their territories' conquest. The same opinion is held by I. Kazantsev when estimating the Russia's position in Central Asia as the position of all enlightened states being in contact with the semi-savage, migrating tribes.

In the authors opinion, the states have to use force: «Asian peoples due to their specifics respect power/force, moral power of the reason and inter- ests of civilization has no power over them» (Kazantsev, 1867: 134).

The following direction in the Russian pre-revolutionary historiography considers that Russia's conquests were connected with the civilizational mission performance. That is based on the false assumption of the low level of civilizational development of the Kazakh people or its total absence. The bright representative of that direction was L.F. Kostenko who wrote: «out of the good qualities of Kygyzes I should mention their ability of easy adoption of the higher civilization ... They are aware of the Russians' superiority and do not run away from the education» (Kostenko, 1890: 34). Another author under the initials A. V. L., writes that spread of the European civilization in Asia is the great historical objective that must be performed by two great powers - Russia and England. The noted that through the conquest was spread Arian race with its civilizations roots by Russians and Englishmen in the Asian space: «So, in front of that forgotten, covered by wilderness cradle are standing new armed representatives of the enlightening race .... fully aware of their power and understanding instinctively the inevitability of the future, they are obsessed by a new conquest after the previous one, even without the deliberately planned intention. They are driven forward by the historical necessity» (A.V.L, 1868:770). It should be noted that the authors by their works emphasized the significance of the European civilization and put its above the civilizations of the East; и Востока; that theory was incorporated into the mindset of the Russian researchers for the year to follow and can be observed nowadays. We consider that the correct tendency present in scholars' to comprehend the history of peoples in holistic way, as some unit, general system, with no confrontation between «primitive» and «civilized» peoples.

Thus, we want to pay attention that representatives of the above-mentioned directions in the Russian pre-revolutionary historiography differed only in defining the reasons and methods of the conquest of Kazakhstan and Central Asia. The common feature is desire to emphasize exceptional role of the Russian people, justify the offensive expansion o Russian and colonization policy.

In late XIX - early XX centuries were published the works of the liberal authors, one of them was orientalist N.I. Veselovsky, who addressed the problem of the Kazakh people attitude to the Russian conquests. When being in the Turkestansky kray with the archeological expedition he was interested in collecting opinions of the native people to the expansion of the Russian troops and changes in their 
lives that occurred resulting from the colonization. "We must listen to the other side, in that particular case, the losing one, otherwise we only with the official reports and stories of the participants from our side make create unilateral stance and make a wrong view on the local population» (Veselovsky, 1894: 11), - wrote N.I. Veselovsky. In his opinion that information was necessitated for the successful influence on the «aborigines», given as an example in the story of Khalibay. The author points at the lack of hatred to the conquerors and high evaluation of the Russian power. A.I. Dobrosmyslov in his works raised the issue on the need to study history, lifestyle and economics of the indigenous population: «We can find a lot of instructive in their historical past (Dobrosmyslov, 1902: 493). The researcher correctly stated that is must be launched as soon as possible because the "coming culture of the West promises in the shortest time completely change, if not at all, but at least introduce many changes alien to the original culture» (Dobrosmyslov,1902: 494). The author considered that tsarism wanted to strengthen Russian civic stance through gradual taming of Kazakhs to sedentarize. Another representative of that approach - A.Y. Alektorov - pointed at the need to investigate «Kyrgyz manuscripts», that are very original, influenced by place and time. Simple uneducated Kyrgyz wrote whatever he wanted and how he wanted to do that» (Alektorov, 1894). Those manuscripts are evaluated by A.Y. Alektorov higher (in terms of originality), than the works of I. Altynsarin and C. Valikahnov that got education under the guidance of highly educated Russian people, that «have Russian spirit, Russia smells there» (Alektorov, 1894). Actually, the world outlook of C. Valikhanov was influenced by the interactions with the representatives of the Russian intelligentsia and activities in the Military-Scientific committee of the General Headquarters. He put many efforts on Kazakhs' joining the Russian and European culture.

The next important aspect of the Kazakhstan's joining the Russian empire is the issue of what the joining gave Russia and the local population? These two points intertwined and always were very close to each other, and many authors did not avoid measuring: what "we gave» and what «we got». More often was described «wonderful life» of Kazakh people after joining the Russian empire, and materials on that topic were of propagandistic character. "The Russian power, - I. Lvov wrote in 1868, - brought to the Central Asia the guarantee of life and guarantee of property, two precious benefits for a man, reasonable life is unthinkable with- out them, benefits unseen in the khanates before» (Lvov, 1868: 173). In opinion of L.F. Kostenko, Russia acquires «abundance of raw materials», «trade development», "Central Asia can serve as a transit for trade of Russia and the East, and south of Asia ...finally from the firm establishment of our control in Central Asia will grow our political influence in Europe» (Kostenko,1890: 328). For the Kazakh population, the author notes: it is end of the tribal feuds, growth of literacy, adoption of European culture and science. Big importance is attached to colonization, that would «bring considerable benefit by the following: 1) would give poor people occupy free places; 2) Russian by their model would encourage the locals to get into economic activities in agriculture and industry, and 3 ) they will provide free labor force for factories and plants, while aborigines can not be employed» (Kostenko, 1890: 328).

The same trend is followed in the estimates of benefits for Russia in the works of A.Semenov, F. Tsherbina, F. Lobysevich, N.N. Balkashin, whose major positions include the following:

- increase of Russian trade turnover;

- exploitation of the natural resources of the conquered kray;

- use of the territory as a transit between Europe and Asia;

- development of market for Russian manufactured goods;

- development of communications links;

- free lands for migration.

Thus, the work of Y. Kologrivov «Russian possessions in Central Asia» emphasizes that «our advance to Central Asia caused originally by the need to protect from the Asians, served a good service to the Russian industry and trade, brought us closer to China, and opened the route to India» (Kologrivov, 1888:35).

In the pre-revolutionary historiography was actively promoted the idea that inhabitants of Kazakhstan and Central Asia got many benefits rather than Russia. What they were in? The following is given as benefits:

- absence of the external threat;

- end of tribal feuds;

- trade development;

- decrease of duties and freedom from military service;

- life level improvement;

- adoption of the European civilization.

These conclusions again stress the direction of the Russian authors materials to ground «civiliza- 
tional mission of Russia» and benefits it brought. Of course, statement of the big benefit to Kazakhstan is not correct, first of all because as result of the joining to Russia Kazakhs lost their independence, and despite some positive changes, the above mentioned benefits, in general they were not good. But some works raised the issue on «benefits» that did not lead to prosperity of the people in Kazakhstan and Central Asia. N.L. Mordvinov in the work «Administration of the sedentary inorodtsys of Turkestan» correctly points that: "seemingly if the sedentary population is to be rich, or well-off, then meanwhile are observed phenomena that prove poor life standing of the local people, than it was expected»(Mordvinov, 1899: 239). I his later works, the author described a negative role of Russians, accusing them in teaching the officials from the local people the methods of corruption and bribery, that led to adverting people from the reform's approval.

O. Shkapsky in the article «Some data for highlighting the Kyrgyz question» noted: «Having established peace in the steppe and ending all feuds there between Kyrgyzes, Kokand and Khiva predators, we seemed to create conditions for peaceful development of Kyrgyz economy, that must increase their economic ... but when the attempt were made to understand what goes on the economy of the Kyrgyz-nomad, they led to the opposite understanding on their welfare» (Shkapsky, 1897: 44). The reasons for that the author finds in the unsatisfactory performance of the local administration and non-preparedness of the indigenous population to self-administration. But of course, the works that critically assessed the activities of the tsarist administration were few. Mostly the works of the Russian authors were aimed to justify the activities of Russia.

\section{Conclusion}

Thus, the published materials mostly were not of historical research type. The authors wrote on the facts and events that did not get into historical past. For the Russian historiography address to history was one of the proof methods for some statements and propositions concerning the contemporary times. The interest to history of Kazakhs to great extent was caused by the need to study and master a new colony, but the authors of the above mentioned works were people of their time, and in their views were not free from the influence of the mission and tasks, put on them by the ideology imperial ideology. Most works are characterized by descriptiveness, weak sources base, lack or absence of historical assessment of the factual data, ungrounded conclusions and generalizations. The problem of the Russian protectorate adoption is given from the "civilizational mission». The representatives of the official aristocratic- bourgeois direction reflected the problem as the inevitable historical act - «Russia is a powerful empire brining benefits»; differences were only in defining the reasons and motives of penetration of Russia into Kazakhstan and Central Asia. That direction practically did not envision a critical assessment of the tsarist government activities in Kazakhstan.

The representatives of the liberal and democratic direction reveal the interest to the history of Kazakh people raise the issue of the benefits from the joining of Kazakhstan to Russia, making attempts to critically estimate the colonial policy of tsarism. Research and analysis of the problem of Kazakhstan's joining the Russian empire in the pre-revolutionary historiography are needed to make a full picture to comprehend the effects of the historical event.

\section{References}

Abaza K.K. (1902). Zavoyevaniye Turkestana [Conquest of Turkestan]. Sankt Peterburg. $310 \mathrm{~s}$.

Alektorov A.Ye. (1894). Kirgizskiye rukopisi [Kyrgyz manuscripts]. Astrakhan’, Astrakhanskiy vestnik, №1393.

A.V.L. (1868).Nashi dela v Turkestanskom kraye [Our affairs in the Turkestansky kray]. Moskva, Vestnik Yevropy.

Belyavskiy A.(1885). Materialy o Turkestane [Materials on Turkestan]. Sankt Peterburg.

Venukov M.I. (1878). Postupatel'noye dvizheniye v Crednyuyu Aziyu [Gradual expansion Russia to Middle Asia]. Sankt Peterburg, T.3. S. 58-106.

Venukov M.I. (1880). Priobreteniya zemli i ustupki Rossii za posledniye tridtsat' let [Land acquisitions and concessions of Russia over the last thirty years]. Moskva, Russkaya mysl', № 4.

Veselovskiy N.(1894). Kirgizskiy rasskaz o russkikh zavoyevaniyakh v Turkestanskom kraye.[ Kyrgyz story on Russian conquests in the Turkestansky kray]. Sankt Peterburg.

Voyennyy sbornik (1898).Vodvorenie rossiyskoy vlasti v Srednyuyu Aziyu [Establishment of the Russian power in Central Asia]. Sankt Peterburg, №8.

Dobrosmyslov A.I. (1902). Turgayskaya oblast'. Istoricheskiy ocherk [Turgaiskaya oblast. Historical survey ]. Tver, S. 257524.

Kazantsev I. (1867). Opisaniye kyrgyz-kaysakov [Description of Kyrgyz-Kaisak]. Sankt Peterburg. 
Kologrivov Y.V.(1888) Russkiye vladeniya v Sredney Azii [Russian possessions in Central Asia]. Sankt Peterburg.

Kostenko L.F.(1890). Srednyaya Aziya i vodvoreniye v ney russkoy grazhdanstvennosti [Central Asia and the establishment of Russian citizenship in it]. Sankt Peterburg, T.XIII. 358 s.

Lvov I. (1868). Zavoyevaniye Turkestanan [Conquest of Turkestan]. Moskva, Russkiy vestnik, №7.

Maksheyev A.I.(1890) Istoricheskiy obzor Turkestana i nastupatel'nogo dvizheniya v nego russkikh [Historical review of Turkestan and offensive motion in him Russians].Sankt Peterburg, $370 \mathrm{~s}$.

Mordvinov N.L. (1899). Administratsiya osedlykh inorodtsev Turkestana. [Administration of the sedentary inorodtsys of Turkestan]. Sankt Peterburg, Russkiy vestnik, №7

Potanin G. (1861) Zametki o Sibirskom kazach'yem voyske [ Notes on the Siberian Qazak troops]. Sankt Peterburg, Voyennyy Sbornik. №5-6. T.19.

Terentiyev M.A.(1906). Istoriya zavoyevaniya Crednei Aziyu [History of conquest The history of the conquest of Middle Asia]. Sankt Peterburg.

Shemonskiy A. (1910). Voyennaya istoriya russkogo dvizheniya v Srednei Azii [Military history of the Russian advance in Middle Asia]. Tashkent.

Shkapskiy O. (1897). Nekotoryye dannyye dlya osveshcheniya kirgizskogo voprosa [Some data to shed light on the Kyrgyz issue]. Sankt Peterburg, Russkaya mysl', № 7. S.44-45. 